\title{
Opinion \\ UNAVOIDABILITY OF SINO-AMERICAN RIFT: HISTORY OF STRATEGIC DECOUPLING
}

\author{
Anis H Bajrektarevic \\ International Law \& Global Political Studies, Vienna, Austria \\ anis@corpsdiplomatique.cd
}

\begin{abstract}
Does our history only appear overheated, while it is essentially calmly predetermined? Is it directional or conceivable, dialectic and eclectic or cyclical, and therefore cynical? Surely, our history warns (no matter if the Past is seen as a destination or resource). Does it also provide for a hope? Hence, what is in front of us: destiny or future?

Theory loves to teach us that extensive debates on what kind of economic system is most conductive to human wellbeing is what consumed most of our civilizational vertical. However, our history has a different say: It seems that the manipulation of the global political economy (and usage of fear as the currency of control) - far more than the introduction of ideologies is the dominant and arguably more durable way that human elites usually conspired to build or break civilizations, as planned projects.
\end{abstract}

Keywords: US, China, decoupling, geopolitics, technology, money, freedoms, multilateralism

\section{Introduction}

Americans performed three very different policies on the People's Republic: From a total negation (and the Mao-time mutual annihilation assurances), to Nixon's sudden cohabitation. Finally, a Copernican-turn: the US spotted no real ideological differences between them and the post-Deng China. This signalled a 'new opening': West imagined China's coastal areas as its own industrial suburbia. Soon after, both countries easily agreed on interdependence (in this marriage of convenience): Americans pleased their corporate (machine and tech) sector and unrestrained its greed, while Chinese in return offered a cheap labour, no environmental considerations and submissiveness in imitation. Both spiced it by nearly religious approach to trade.

However, for each of the two this was far more than economy, it was a policy - Washington read it as interdependence for transformative containment and Beijing sow it as interdependence for a (global) penetration. In the meantime, Chinese acquired more sophisticated technology, and the American Big tech sophisticated itself in digital authoritarianism - 'technological monoculture' met the political one.

But now with a tidal wave of Covid-19, the honeymoon is over.

(These days, many argue that our C-19 response is a planetary fiasco, whose size is yet to surface with its mounting disproportionate and enduring secondary effects, causing tremendous 
socio-economic, political and psychosomatic contractions and convulsions. But, worse than our response is our silence about it. ${ }^{1}$

E.g. Le Monde Diplomatique - while examining the possible merge between tech oligopoly and political monopoly - claims: "Political decisions have been central in shaping this tragedy - from the destruction of animal habitats, to the asymmetric funding of medical research, to the management of the crisis itself. They will also determine the world into which we emerge after the worst is over." Over the past 30 years, every critical conjecture had a similar epilogue: pardon and enhancement for the capital, a burden and suppression for the labour. The C-19 is no exception to it: Ever since early lockdowns of March 2020, the (gross) capital flows unhindered while the labour, ideas and humans are under the house arrest. The XXI century frontline is the right to health and labour, privacy and human rights. (LMD, IV20))

Still to be precise, the so-called virus pandemic brought nothing truly new to the already overheated Sino-American relations and to the increasing binarization of world affairs: It only amplified and accelerated what was present for quite some time - a rift between alienated power centres, each on its side of Pacific, and the rest. No wonder that the work on the C-19 vaccine is more an arms race that it is a collaborative humanistics.

Would it be about an expansion of techno-totalitarian model of government as an alternative to liberal democracy? Devolutionary singularisation into techno-feudalism? And, is now a time to return to the nation-state, a great moment for all dictators-in-waiting to finally build a cult of personality? Hence, will our democracy be electro-magnetised and vaccinated for a greater good (or greedier 'god')?

This text examines a prehistory of that rift; and suggests possible outcomes past the current crisis.

\footnotetext{
${ }^{1}$ It is an established fact that the quintessence of Nazism was not Hitler and the circle of darkness around him. It was rather a commonly shared 'banality of crime' atmosphere: an acceptance of ordinary village people living next to Auschwitz, Treblinka, Dachau ... The day when questioning stops and silent acceptance becomes a 'new normal' is a day when fascism walks in a big time. Or, manufacturing consent through choice architecture, of a fear-imprisoned psychology. So, our C-19 response illustrates - the argument goes - nothing else but a social pathology: the non-transparent concentration of power and our overall democracy recession - further bolstering surveillance and social control systems; lasting consequences of cutbacks, environmental holocaust, privatisation of key intergovernmental and vital national institutions, ill-fated globalisation on (overly allopathic, mandated drugs -centred) healthcare, and luck of public data commons. Pandemic or plundermic ...

Early lockdowns, mid-March 2020, were justified by a need to flatten the curve of the 'sudden' virus impact, since there were no enough hospital beds. In the meantime, the lockdowns were extended and widened, curves not arguable changed. Still, for the past 9 months, there is hardly any new hospital built in the EU although the nonessential medical services are by and far suspended. Nor, there is any massive investment into general health prevention. The only visible infrastructure growth is in 5/6G networks expansion.

Following a simple ratio that the one's level of health is genetic expression of life-style choices made, it is no surprise that there are also growing speculations if the lockdown - as the most notorious expression of monofocal perspective and rejection to any scientific debate-based integrated judgment, is invasion or protection: Whether the aim is a herd-immunity or herd loyalty (and to it related growing, yet still unrefuted, rumour that the eventual C-19 vaccine might contain biohacking nano-properties which establish backdoor interface via extensively set $5 / 6 \mathrm{G}$ ). And, if is there any back-to-normal exit from the crisis or will this disaster 'turned into planetary terror, through global coup d'état' be exploited to further something already pre-designed (with a fear, not as a sideeffect, but rather as a manufactured tool to gain control) - more related to biotronics and demographics, than to health and economics or any common social purpose.
} 


\section{Origins of Future}

Does our history only appear overheated, while it is essentially calmly predetermined? Is it directional or conceivable, dialectic and eclectic or cyclical, and therefore cynical? Surely, our history warns (no matter if the Past is seen as a destination or resource). Does it also provide for a hope? Hence, what is in front of us: destiny or future? ${ }^{2}$

Theory loves to teach us that extensive debates on what kind of economic system is most conductive to human wellbeing is what consumed most of our civilizational vertical. However, our history has a different say: It seems that the manipulation of the global political economy (and usage of fear as the currency of control) - far more than the introduction of ideologies is the dominant and arguably more durable way that human elites usually conspired to build or break civilizations, as planned projects. Somewhere down the process, it deceived us, becoming the self-entrapment. How?

One of the biggest (nearly schizophrenic) dilemmas of liberalism, ever since David Hume and Adam Smith, was an insight into reality: Whether the world is essentially Hobbesian or Kantian. As postulated, the main task of any liberal state is to enable and maintain wealth of its nation, which of course rests upon wealthy individuals inhabiting the particular state. That imperative brought about another dilemma: if wealthy individual, the state will rob you, but in absence of it, the pauperized masses will mob you.

The invisible hand of Smith's followers have found the satisfactory answer - sovereign debt. That 'invention' meant: relatively strong central government of the state. Instead of popular control through the democratic checks-\&-balance mechanism, such a state should be rather heavily indebted. Debt - firstly to local merchants, than to foreigners - is a far more powerful deterrent, as it resides outside the popular check domain.

With such a mixed blessing, no empire can easily demonetize its legitimacy, and abandon its hierarchical but invisible and unconstitutional controls. This is how a debtor empire was born. A blessing or totalitarian curse? Let us briefly examine it.

The Soviet Union - much as (the pre-Deng's) China itself - was far more of a classic continental military empire (overtly brutal; rigid, authoritative, anti-individual, apparent, secretive), while the US was more a financial-trading empire (covertly coercive; hierarchical, yet asocial, exploitive, pervasive, polarizing). On opposite sides of the globe and cognition, to each other they remained enigmatic, mysterious and incalculable: Bear of permafrost vs. Fish of the warm seas. Sparta vs. Athens. Rome vs. Phoenicia... However, common for both (as much as for China today) was a super-appetite for omnipresence. Along with the price to pay for it.

Consequently, the Soviets went bankrupt by mid 1980s - they cracked under its own weight, imperially overstretched. So did the Americans - the 'white man burden' fractured them

\footnotetext{
${ }^{2}$ Flow and irreversibility (as well as the non-directionality and the Boltzmann's unfolding) of time is one of the fundamental principles that governs visible (to say; comprehensible) universe. If and when so, the Future itself must be certain, but unshaped. Hence, Future is a manifestation of the second law of thermodynamics (one of the fundamental principles of chemo-physics that governs us), but it also has to be (a net sum of) our collective projection onto the next: Collapse of the (multivectoral) probability and its realisation into (a four dimensional) possible tomorrow. For a clerical reason, we tend to deduce future events from human constructs (known as the theoretical principles) or to induce them from deeply rooted/commonly shared visions (known as past experience).
} 
already by the Vietnam war, with the Nixon shock only officializing it. However, the US imperium managed to survive and to outlive the Soviets. How?

The United States, with its financial capital (or an outfoxing illusion of it), evolved into a debtor empire through the Wall Street guaranties. Titanium-made Sputnik vs. gold mine of printedpaper... Nothing epitomizes this better than the words of the longest serving US Federal Reserve's boss, Alan Greenspan, who famously quoted J.B. Connally to then French President Jacques Chirac: "True, the dollar is our currency, but your problem". Hegemony vs. hegemoney.

\section{House of Cards (Forever $r>g$ )}

Conventional economic theory teaches us that money is a universal equivalent to all goods. Historically, currencies were a space and time-related, to say locality-dependent. However, like no currency ever before, the US dollar became - past the WWII - the universal equivalent to all other moneys of the world. According to history of currencies, the core component of the non-precious metals' money is a so-called promissory note - intangible belief that, by any given point in future, a particular shiny paper (self-styled as money) will be smoothly exchanged for real goods.

Thus, roughly speaking, money is nothing else but a civilizational construct about imagined/projected tomorrow - that the next day (which nobody has ever seen in the history of humankind, but everybody operates with) definitely comes (i), and that this tomorrow will certainly be a better day then our yesterday or even our today (ii).

This and similar types of collective constructs (horizontal and vertical) over our social contracts hold society together as much as its economy keeps it alive and evolving. Hence, it is money that powers economy, but our blind faith in constructed (imagined) tomorrows and its alleged certainty is what empowers money.

Tellingly, the universal equivalent of all equivalents - the US dollar - follows the same pattern: Bold and widely accepted promise. For the US, it almost instantly substan-tiates extraterritorial economic projection: American can print (any sum of) money without fear of inflation. (Quantitative easing is always exported; value is kept home.)

(Empire's currency loses its status when other nations lose confidence in ability of that imperial power to remain solvent. For the pre-modern and modern history, it happened with 5 powers two Iberian, Dutch, France and the UK - before the US dollar took the role of world reserve currency. Interestingly, each of the empires held it for roughly a century. The US century is just about to expire, and there are already contesters, territorial and non-territorial, symmetric and asymmetric ones. On offer are tangibles and intangibles: gold, cryptocurrencies, and biotronics/nano-chemoelectricals.)

But, what does the US dollar promise when there is no gold cover attached to it ever since the time of Nixon shock of 1971 ?

Pentagon promises that the oceanic sea-lanes will remain opened (read: controlled by the US Navy), pathways unhindered, and that the most traded world's commodity - oil, will be delivered. So, it is not a crude or its delivery what is a cover to the US dollar - it is a promise that oil of tomorrow will be deliverable. That is a real might of the US dollar, which in return finances Pentagon's massive expenditures and shoulders its supremacy. 
Admired and feared, Pentagon further fans our planetary belief in tomorrow's deliverability if we only keep our faith in dollar (and hydrocarbons' energized economy), and so on and on in perpetuated circle of mutual reinforcements.

(Supplementing the Monroe Doctrine, President Howard Taft introduced the so-called 'dollar diplomacy" - in early XX c. - that "substitutes dollars for bullets". This was one of the first official acknowledgements of the Wall Street - Pentagon symbiotic link.)

These two pillars of the US might from the East coast (the US Treasury/Wall Street and Pentagon) together with the two pillars of the West coast - both financed and amplified by the US dollar, and spread through the open sea-routs (Silicone Valley and Hollywood), are an essence of the US posture. Country that hosts such a dream factory, as the US does Hollywood, is easy to romanticize - though other 3 pillars are to take and to coerce.

This very nature of power explains why the Americans have missed to take the mankind into completely other direction; towards the non-confrontational, decarbonized, de-monetized/definancialized and de-psychologized, the self-realizing and green humankind. In short, to turn history into a moral success story. They had such a chance when, past the Gorbachev's unconditional surrender of the Soviet bloc, and the Deng's Copernicus-shift of China, the US - unconstrained as a lonely superpower - solely dictated terms of reference; our common destiny and direction/s to our future/s.

\section{Winner is rarely a game-changer}

Sadly enough, that was not the first missed opportunity for the US to soften and delay its forthcoming, imminent multidimensional imperial retreat. The very epilogue of the WWII meant a full security guaranty for the US: Geo-economically $-54 \%$ of anything manufactured in the world was carrying the Made in USA label, and geostrategically - the US had uninterruptedly enjoyed nearly a decade of the 'nuclear monopoly'. Up to this very day, the US scores the biggest number of N-tests conducted, the largest stockpile of nuclear weaponry, and it represents the only power ever deploying this 'ultimate weapon' on other nation.

To complete the irony, Americans enjoy geographic advantage like no other empire before. Save the US, as Ikenberry notes: "...every major power in the world lives in a crowded geopolitical neighborhood where shifts in power routinely provoke counterbalancing". Look the map, at Russia or China and their packed surroundings. The US is blessed with its insular position, by neighboring oceans. All that should harbor tranquility, peace and prosperity, foresightedness.

Why the lonely might, an empire by invitation did not evolve into empire of relaxation, a generator of harmony? Why does it hold (extra-judicially) captive more political prisoners on Cuban soil than the badmouthed Cuban regime has ever had? Why does it remain obsessed with armament for at home and abroad? Why existential anxieties for at home and security challenges for abroad? Eg. $78 \%$ of all weaponry at disposal in the wider MENA theater is manufactured in the US, while domestically Americans - only for their civilian purpose - have 1,2 small arms pieces per capita.)

Why the fall of Berlin Wall 30 years ago marked a beginning of decades of stagnant or failing incomes in the US (and elsewhere in the OECD world) coupled with alarming inequalities. What are we talking about here; the inadequate intensity of our tireless confrontational push or about the false course of our civilizational direction? 
Indeed, no successful and enduring empire does merely rely on coercion, be it abroad or at home. The grand design of every empire in past rested on a skillful calibration between obedience and initiative - at home, and between bandwagoning and engagement - abroad. In XXI century, one wins when one convinces not when one coerces. Hence, if unable to escape its inner logics and deeply rooted appeal of confrontational nostalgia, the prevailing archrival is only a winner, rarely a game-changer.

How did we miss to notice it before? Simply, economy -right after history- is the ideologically most 'colored' scientific discipline of all.

To sum up; After the collapse of the Soviet Union, Americans accelerated expansion while waiting for (real or imagined) adversaries to further decline, 'liberalize' and bandwagon behind the US. One of the instruments was to aggressively push for a greater economic integration between regional and distant states, which - as we see now, passed the 'End-of-History' euphoria of $1990 \mathrm{~s}$ - brought about (irreversible) socio-political disintegration within each of these states.

\section{A Country or a Cause, Both or None?}

Expansion is the path to security dictatum, of the post-Cold War socio-political and (hyperliberal) economic mantra, only exacerbated the problems afflicting the Pax Americana, which acidified global stewardship; hence oceans, populations and the relations to the unbearable levels. That is why and that is how the capability of the US to maintain its order started to erode faster than the capacity of its opponents to challenge it. A classical imperial self-entrapment (by the so-called bicycle theory: keep pedalling same way or topple over).

Clearly, the US post-Cold War preponderance is now challenged in virtually every domain: America can no longer operate unrestrained in the traditional spheres of land, sea and air, not in newer ones like the (near and deeper) outer space and cyberspace. The repeated failure to notice and recalibrate such an imperial emasculation and retreat brought the painful hangovers to Washington, the most noticeably, by the last two presidential elections. ${ }^{3}$ Inability to manage the rising costs of sustaining the imperial order only increased the domestic popular revolt and political pressure to abandon its 'mission' altogether. (E.g. during the peak times of its longest - still ongoing - foreign intervention, the US was spending some \$110 billion per annum in Afghanistan, roughly 50\% more than annual American federal spending on education.) Perfectly hitting the target to miss everything else ...

In short, past the Soviet collapse Americans intervened too much abroad, regulated too little at home, and delivered less than ever - both at home and abroad. Such model attracts none. ${ }^{4}$ No wonder that today all around the globe many do question if the States would be appealing ever again. Domestically, growing number of people perceive foreign policy mostly as an expensive

\footnotetext{
${ }^{3}$ Average American worker is unprotected, unorganised/disunionised, disoriented, and pauperised. Due to (the US corporate sector induced) colossal growth of China, relative purchasing power of American and Chinese labourer now equals. At present, the median US worker would frictionlessly accept miserable work conditions and dismal pay, not too different from the one of the Chinese labourers - just to get a job. The first to spot that and then wonderfully exploited it was the Trump team.

4 "A rogue superpower ... colossus lacking moral commitments ... aggressive, heavily armed, and entirely out for itself. ... some US security guaranties have started to look like protection rackets. ... participates in international institutions but threatens to leave them when they act against US narrow interests; and promotes democracy and human rights, but mainly to destabilize geopolitical rivals" - enumerates some in the long list of contemporary US sins prof. Beckley (Beckley, M. (2018) Unrivaled: Why America Will Remain the world's Sole Superpower, Cornell University Press).
} 
destruction, divinized trade and immigration as destroyers of jobs and communities. Its political system is unable to decouple and deconcentrate wealth and power which suffocates the very social fabrics.

Hence, Americans are not fixing the world anymore. They are only managing its decline. Look at their footprint in former Yugoslavia, Afghanistan, Iraq, Pakistan, Georgia, Libya, Syria, Ukraine or Yemen - to mention but a few. Violence as a source of social cohesion is dying out.

When the Soviets lost their own indigenous ideological matrix and maverick confrontational stance, and when the US dominated West missed to triumph although winning the Cold War, how to expect from the imitator to score the lasting moral or even a temporary economic victory?

Dislike the relationship with the Soviets Union which was on one clear confrontational acceptance line from a start until its very last day, Americans performed three very different policies on the People's Republic: From a total negation (and the Mao-time mutual annihilation assurances), to Nixon's sudden cohabitation. (Withdrawal of recognition from Formosa to Beijing formally opened relations between the two on 1 January 1979. On a celebratory tour to America later that very month, Deng Xiaoping recommended that China and the US were 'duty bound to work together [and unite] to place curbs on the polar bear').

Finally, a Copernican-turn: the US spotted no real ideological differences between them and the post-Deng China. This signalled a 'new opening' - China's coastal areas to become West's industrial suburbia. Soon after, both countries easily agreed on interdependence: Americans pleased their corporate (machine and tech) sector and unrestrained its greed, while Chinese in return offered a cheap labour, no environmental considerations and submissiveness in imitation. However, for both it was far more than economy lubricated by sanctified free trade, it was a policy - Washington read it as interdependence for transformative containment and Beijing sow it as interdependence for (global) penetration. American were left in a growing illusion that the Sino growth is on terms defined by them, and Chinese - on their side - grew confident that these terms of economic growth are only accepted by them.

The so-called Financial crisis 2008/09 (or better to say the peak time of Casino economy) undermined positions of the largest consumer of Chinese goods (US), and simultaneously boosted confidence of the biggest manufacturer of American products (PRC). Consequently, soon after; by 2012, Beijing got the first out-of-Deng's-line leadership. (One of the famous Asia's Bismarck dictatums was 'hide the capabilities, bide your time' - a pure Bismarckian wisdom to deter any domestic imperialism in hurry.)

However, in the process of past few decades, Chinese acquired more sophisticated technology, and the American Big tech sophisticated itself in digital authoritarianism.

But, as America (suddenly) returns home, the honeymoon seems over now.

Why does it come now? Washington is not any more able to afford treating China as just another trading partner. Also, the US is not well situated to capitalize on Beijing's eventual belligerence (especially with Russia closer to China than it was ever before).

The typical line of western neo-narrative goes as: 'The CCP exploited the openness of liberal societies and particularly its freedom of speech as to plunder, penetrate and divert'. And; 'Beijing has to bear the reputational costs of its exploitative practices'. 
Accelerating collision course already leads to the subsequent calls for a strategic decupling (at best, gradual disengagements) of the two world's largest economies and of those in their orbits. Besides marking the end of global capitalism which exploded since the fall of Berlin Wall, this may finally trigger a global realignment. The rest of the world would end up - willingly or not - in the rival (trade) blocks. It would not be a return to 1950s and 1960s, but to the pre-WWI constellations.

Epilog is plain to see: Neither more confrontation and more carbons nor more weaponized trade and traded weapons will save our day. It failed in our past; it will fail again any given day.

\section{Entrapment in Imitation}

Interestingly, China opposed the I World, left the II in rift, and ever since Bandung of 1955 it neither won over nor (truly) joined the III Way. Today, many see it as a main contestant, a leader from the global South. But, where is a lasting success?

There is a near consensus among the economists that China owes its economic success to three fundamental factors. Firstly, it is that the People's Republic embraced an imitative economic policy (much like Japan, Singapore, Taiwan or ROK did before) through Deng-proclaimed opening. Second goes to a modest domestic consumption, and German-like thick home savings. Finally, as the third factor that the economists attribute to Chinese miracle, is a low production costs of Sino nation - mostly on expenses of its aging demography, and on expenses of its own labor force and country's environment. ${ }^{5}$ In short, its growth was neither green, nor inclusive, nor sustainable. Additionally, many would say that Beijing mixes up its nearly obsessive social control, environmental negligence and its dismal human and minority rights with the right to development.

Therefore, many observers would agree that the so-called China's miracle is a textbook example of a highly extractive state that generates enormous hidden costs of its development, those being social, environmental and health ones as much as expanding and lasting. And indeed, energy-intensive exports (especially carbon footprint) from China as well as its highly polluting industrial practices (overall ecological footprint) were introduced to and then for a long while tolerated in People's Republic by the West.

Further on, China accepted a principled relation with the US (Russia, too), but insists on transactional one with its neighbors and BRI (Belt and Road Initiative) clients. This reduces the choice (offered by the two protagonists) on selection between the colonial democracy and authoritarian paternalism.

None of the above has an international appeal, nor it holds promise to an attainable future. Therefore, no wonder that the Imitative power fights - for at home and abroad - a defensive

\footnotetext{
${ }^{5}$ High tech and know-how appropriation via mandated/forced technology transfers and copy-cats, joint ventures, discriminatory patent-licencing practices and cross-sectoral state-led industrial modernisation have lifted China up the value chain. No wonder that its GDP per capita has jumped from \$194 (1980) to over \$9,000 (2019). Beijing is modernising its navy, and is engaged in international economic expansion and geopolitical projection via its Belt and Road Initiative, and so far has bought, built or is operating 42 ports in 34 countries. In the meantime, Washington is publicly lamenting return to a 'worker-focused trade policy' - as the US Trade Representative Robert E. Lighthizer calls it - and openly objecting to both 'market-distorting state capitalism in China and a dysfunctional WTO'. "No trade policy decision since the end of WWII proved more devastating to working people than the extension of permanent normal trade relations to China in 2000. Despite President Clinton's predictions..., the opposite occurred" - he concludes. (FAM, 99/04/20)
} 
ideological battle and politics of cultural reaction. Such a reactive status quo has no intellectual appeal to attract and inspire beyond its borders.

So, if for China the XIX was a "century of humiliation", XX "century of emancipation", should it be that the XXI gets labeled as a "century of imitation"?

(The BRI is what the most attribute as an instrument of the Chinese planetary posture. Chinese leaders promised massive infrastructure projects all around by burning trillions of dollars. Still, numbers are more moderate. As the 2019 The II BRI Summit has shown (and the forthcoming BRI Summit of November 2020 may confirm), so far, Chinese companies had invested USD 90 billion worldwide. Seems, neither People's Republic is as rich as many (wish to) think nor it will be able to finance its promised projects without seeking for a global private capital. Such a capital -if ever - will not flow without conditionalities. The Asian Infrastructure Investment Bank (AIIB) and the BRICS or 'New Development' - Bank have some $\$ 150$ billion at hand, and the Silk Road Infrastructure Fund (SRIF) has up to $\$ 40$ billion. Chinese state and semiprivate companies can access - according to the OECD estimates - just another $\$ 600$ billion (much of it tight) from the home, state-controlled financial sector. That means that China runs short on the BRI deliveries worldwide. Ergo, either bad news to the (BRI) world or the conditionalities' constrained China.)

How to behave in the world in which economy is made to service trade (as it is defined by the Sino-American high priests of globalization), while (preservation of domestic jobs and) trade increasingly constitutes a significant part of the big power's national security strategy? And, how to define (and measure) the existential threat: by inferiority of ideological narrative - like during the Cold War; or by a size of a lagging gap in total manufacturing output - like in the Cold War aftermath. Or something third? Perhaps a return to an inclusive growth.

If our civilizational course is still the same - the self-realization of mankind; than the deglobalization would be a final price to pay for re-humanization of labor and overall planetary greening. Are we there yet?

\section{Promise of the Schumann Resonance}

Earlier in this text, we already elaborated on imperial fictions and frictions: Empires and superpowers create their own realities, as they are not bound to 'situation on ground'. For them, the main question is never what they can but what they want in international conduct.

For sure, there is no intellectual appeal in a growth without well-being, education that does not translate into fair opportunity, lives without dignity, liberalization without personal freedom. Greening international relations along with a greening of social fabrics and its economy (including the shift to blue and white, sea and wind, energy) - geopolitical and environmental understanding, de-acidification and relaxation is that missing, third, way for tomorrow.

This necessitates both at once: less confrontation over the art-of-day technology and their demonopolized redistribution as well as the resolute work on the so-called Tesla-ian implosive/fusion-holistic systems. That would include the free-transfer non-Hertzian energy technologies (able to avoid life in electromagnetic technologically generated soup of unbearable radiation toxicity, actually able to de-toxicate our troposphere from dangerous fields, waves and frequencies emittance - drawing us closer to Schumann resonance); carbonsequestration; antigravity and self-navigational solutions; bioinformatics and nanorobotics. 
Surely, with the bioinformatics and nanorobotics being free from any usage for eugenics' ends (including the vaccination for microchipping purpose). ${ }^{6}$

In short, more of initiative than of obedience (including more public control over data hoovering). More effort to excellence (creation) than a struggle for preeminence (partition). Leader of the world needs to offer more than just money and intimidation.

'Do like your neighbor' is a Biblical-sounding economic prophecy that the circles close to the IMF love to tirelessly repeat. Indeed, it is hard to imagine a formidable national economic prosperity, if the good neighborly relations are not built and maintained. ${ }^{7}$ Clearly, no global leader has ever in history emerged from a shaky and distrustful neighborhood, or by offering a little bit more of the same in lieu of an innovative technological advancement.

(Eg. many see Chinese $5 \mathrm{G}$ - besides the hazardous electrosmog of IoT that this technology emits on Earth's biota - as an illiberal innovation, which may end up servicing authoritarianism, anywhere. ${ }^{8}$ And indeed, the AI deep learning inspired by biological neurons (neural science) including its three methods: supervised, unsupervised and reinforced learning can end up by being used for the diffusion of digital authoritarianism, predictive policing and manufactured social governance based on the bonus-malus behavioral social credits. ${ }^{9}$ )

Ergo, it all starts from within, from at home; socio-economically and environmentally. Without support from a home base (including that of Hong Kong, Xinjiang and Tibet), there is no game

\footnotetext{
6 Confronting the long-term interests of stakeholders with the short-term interests of shareholders, the multinational and national private sector from both sides of Atlantic exercises disproportionate power in the technological share (infrastructure and data), but also by largely benefiting from massive public research funds while in return paying dismal, negotiable tax if any at all. Far too often it comes with the nondisclosure agreements and other unilaterally beneficial legal instruments as well as with the close ties between the private sector, intelligence agencies and media. The same applies to a big Pharma which increasingly dictates a non-preventive monofocal approach to medicine and research, and controls reporting about it - not always in the name of the public health. Therefore, the above represents the largest underreported threat to our democracy and future societal conduct.

Conclusively, Bioinformatics is a dual-use technology. It has huge weaponization potential for at home and abroad. Consequently, this necessitates a comprehensive legislation which builds up on the Universal Charter and Nuremberg Code and its effective enforcement, nationally and internationality.

${ }^{7}$ Fully aware of it, China and Russia (in their historical and yet still ongoing rapprochement) are pushing on a new Asian continental/regional security organisation. Building on the best legacy of comprehensive pan-European security mechanism - that of the Vienna-based OSCE (Organisation for Security and Cooperation in Europe), these two are committing themselves to and inviting their neighbours to join with the CICBMA (Conference on Interaction and Confidence Building Measures in Asia), architecting the CSTO (Collective Security Treaty Organisation) and the QCCM (Quadrilateral Cooperation and Coordination Mechanism). It is on a top of already elaborate SCO (Shanghai Cooperation Organisation) and well-functioning economic FORAs - China-run AIIB (Asian Infrastructure Investment Bank) and Russia-backed EAEU (Eurasian Economic Union). Hence, in a matter of just two decades the central section of Eurasian continent became the most multilateralised - and therefore stabile, region of the world. The collective one is far better than the bilateral or selective/Ad Hoc security arrangement preferred by the US in the Asia-Pacific. Alliances are built on shared interested, solidified by formulated principles and maintained on reliability and predictability - hence, are structural stabilisers.

${ }^{8}$ Seems that China leads but is not alone with its much-criticised bonus-malus social credit system powered by facial recognition technology. Human Rights monitory agencies (including the US Carnegie Endowment's AI Global Surveillance Index) report that practically each and every of the G-20 countries extensively uses the AIenabled surveillance appliances, including variety of facial recognition programs, aimed at social 'predictability'. Not to mention that such new technologies are particularly dangerous for weak democracies since many of their digital tools are dual use technology.

9 Technology, its innovation and to it related norm-setting institutions are not a fancy item for round-tables' discussions - it is a central element of contemporary global and regional geopolitical competition.
} 
changer. China's home is Asia. Its size and its centrality along with its impressive output is constraining it enough.

Conclusively, it is not only a new, non-imitative, turn of socioeconomics and technology what is needed. Without truly and sincerely embracing mechanisms such as the NAM, ASEAN and SAARC (eventually even the OSCE) and the main champions of multilateralism in Asia, those being India Indonesia and Japan first of all, China has no future of what is planetary awaited the third force, a game-changer, discursive power, lasting visionary and trusted global leader. ${ }^{10}$

If there was ever in history a lasting triumph, this is over by now. In the multipolar world of XXI century dominated by multifaceted challenges and multidimensional rivalries, there is no conventional victory. Revolution or restauration?

\section{Post Scriptum:}

To varying degrees, but all throughout a premodern and modern history, nearly every world's major foreign policy originator was dependent (and still depends) on what happens in, and to, Russia. So, neither a structure, nor content or overall direction of world affairs for the past 300 years has been done without Russia. It is not only a size, but also a centrality of Russia that matters. That is important as much (if not even more), as it is an omnipresence of the US or a hyperproduction of the PR China. Ergo, that is an uninterrupted flow of manufactured goods to the whole world, it is a balancing of the oversized and centrally positioned one, and it is the ability to controllably corrode the way in and insert itself of the peripheral one. The oscillatory interplay of these three is what characterizes our days.

Therefore, reducing the world affairs to the constellation of only two super-players - China and the US is inadequate - to say least. It is usually done while superficially measuring Russia's overall standing by merely checking its current GDP, and comparing its volume and PPP, and finding it e.g. equal to one of Italy. Through such 'quick-fix', Russia is automatically downgraded to a second-rank power status. This practice is as dangerous as it is highly misleading. Still, that ill-conceived argument is one of the most favored narratives which authors in the West are tirelessly peddling. What many analysts miss to understand, is in fact plain to see; throughout the entire history of Russia: For such a big country the only way to survive - irrespectively from its relative weaknesses by many 'economic' parameters - is to always make an extra effort and remain great power.

To this end, let us quickly contrast the above narrative with some key facts: Russia holds the key positions in the UN and its Agencies as one of its founding members (including the Security Council veto right as one of the P5); it has a highly skilled and mobilized population; its society

\footnotetext{
${ }^{10}$ Over the past few months, People's Republic has upped the ante in nearly all of its many territorial disputes and even provoked new ones, in another departure from past practice. Beijing has also reversed course when it comes to its national periphery. "Past Chinese leaders, notably Deng Xiaoping and Jiang Zemin, believed in the institutionalized processes of collective leadership. Xi has disabled or neutralized many of these channels. The world may now be getting a sense of what China's decision-making looks like when a singularly strong leader acts more or less on his own" - noted professor Rapp-Hooper recently in her book. That of course triggers constant shockwaves all over Asia. While Indonesia is contemplating the NAM's reload as well as the ASEAN block strengthening, others are reactive. India and Japan, two other Asian heavyweights (and champions of multilateralism), are lately pushed to sign up on the so-called Indo-Pacific maritime strategy with the United States (balancing the recent Pacific trade deal of RCEP). However, none of these three has any coherent plan on what to do on the Asian mainland. They all three differ on passions, drives and priorities. This is so since the truly pancontinental organization is nonexistent in Asia.
} 
has deeply rooted sense of a special historic mission (that notion is there for already several centuries - among its intellectuals and enhanced elites, probably well before the US has even appeared as a political entity in the first place). Additionally and tellingly, Moscow possesses the world's largest gold reserves (on surface and underground; in mines and its treasury bars); for decades, it masters its own GPS system and the most credible outer space delivery systems (including the only remaining working connection with the ISS), and has an elaborate turnkey-ready alternative internet, too.

Finally, as the US Council of Foreign Relations' Thomas Graham fairly admits: "with the exception of China, no country affects more issues of strategic and economic importance to the US than Russia. And no other country, it must be said, is capable of destroying the US in 30 minutes."

Prof. Anis H. Bajrektarević,

Vienna, 20112020

\section{References}

Halimi, S. (2020), Dès maintenant!, Le Mond Diplomatique (LMD IV/20), Paris France

Piketty, T. (2020), Capital et Idéologie, Éditions du Seuil, Paris France

Thiesse, A-M. (1999), La création des identités nationales: Europe XVIIIe-XXe siècle, Editions du Seuil, Paris,

Khana, P. (2019), The Future is Asian, Simon \& Schuster

Curtain, P.D. (1984), Cross-Cultural Trade in World History, Cambridge University Press

Acemoglu, D. and Robinson, J.A. (2012), Why Nations Fail, Crown Business (Random House) NY

Beckley, M. (2018), Unrivaled: Why America Will Remain the world's Sole Superpower, Cornell University Press

Diamond, J. (2019), Upheaval - Turning Points for Nations in Crisis, Little Brown and Company NY

Mazzucato, M. (2020) The Value of Everything: Making and Taking in the Global Economy Penguin UK

Harari, Y.N. (2018), 21 Lessons for the 21st century, Penguin - Random House UK

Rapp-Hooper, M. (2020), Shields of the Republic: The Triumph and Peril of America's Alliances, Harvard University Press

Lighthizer, R. E. (2020), How to Make Trade Work for Workers, FAM (99/04/20)

Bajrektarević, A. (2012), No Asian Century ..., Addleton Academic Publishers, New York

Graham, T. (2019), Let Russia Be Russia, CFR (FAM, 98-6-19, pg.134) 